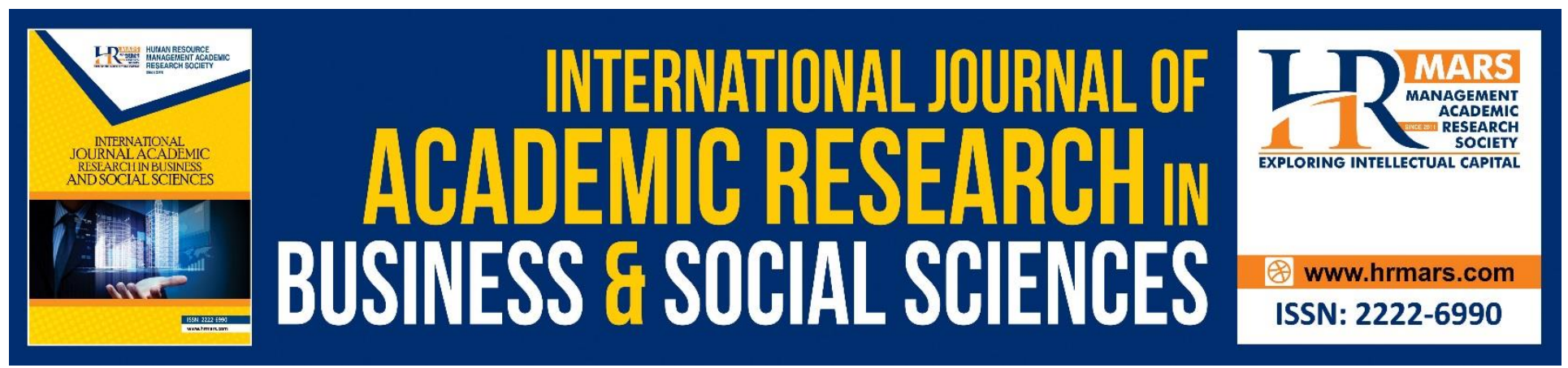

\title{
Knowledge on Doubtful Halal Processed Foods and Muslim Consumer Purchased Behavior
}

Nur Ida Fatihah Bt Che Shalifillizam, Alliffaizi Arsat, Zulhan Othman, Noor
Azmi Ahmad, Rahayu Mokhtar

To Link this Article: http://dx.doi.org/10.6007/IJARBSS/v8-i8/4619

DOI: $\quad 10.6007 /$ IJARBSS/v8-i8/4619

Received: 28 June 2018, Revised: 23 July 2018, Accepted: 29 July 2018

Published Online: 27 August 2018

In-Text Citation: (Shalifillizam, Arsat, Othman, Ahmad, \& Mokhtar, 2018)

To Cite this Article: Shalifillizam, N. I. F. B. C., Arsat, A., Othman, Z., Ahmad, N. A., \& Mokhtar, R. (2018). Knowledge on Doubtful Halal Processed Foods and Muslim Consumer Purchased Behavior. International Journal of Academic Research in Business and Social Sciences, 8(8), 628-638.

Copyright: (C) 2018 The Author(s)

Published by Human Resource Management Academic Research Society (www.hrmars.com)

This article is published under the Creative Commons Attribution (CC BY 4.0) license. Anyone may reproduce, distribute, translate and create derivative works of this article (for both commercial and non-commercial purposes), subject to full attribution to the original publication and authors. The full terms of this license may be seen

at: http://creativecommons.org/licences/by/4.0/legalcode

Vol. 8, No. 8, August 2018, Pg. 628 - 638

Full Terms \& Conditions of access and use can be found at http://hrmars.com/index.php/pages/detail/publication-ethics 


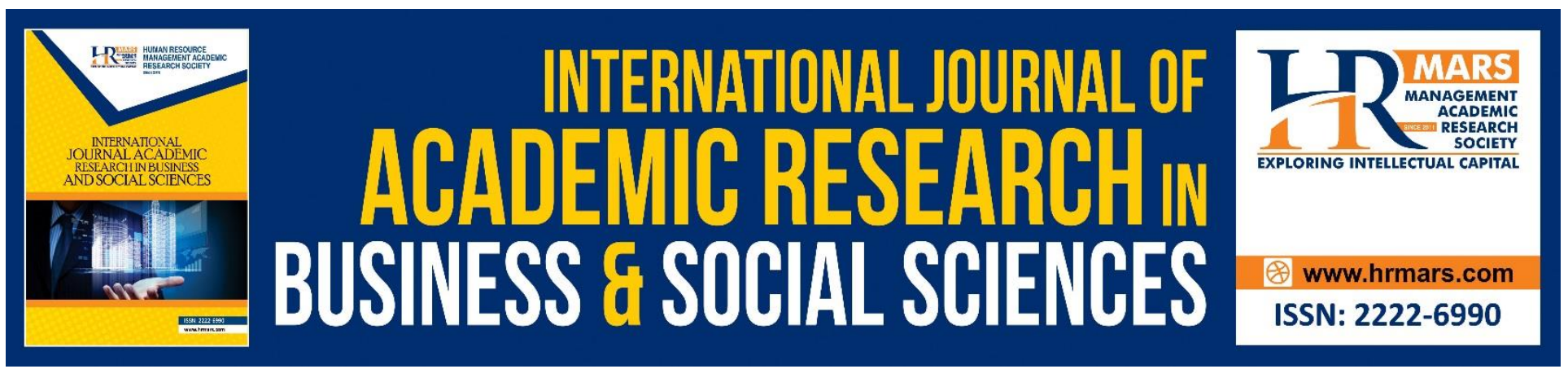

\title{
Knowledge on Doubtful Halal Processed Foods and Muslim Consumer Purchased Behavior
}

\author{
Nur Ida Fatihah Bt Che Shalifillizam
}

Faculty of Hospitality and Tourism, Taylor's University

E-mail: nuridafatihahcheshalifullizam@sd.taylors.edu.my

\author{
Alliffaizi Arsat \\ Faculty of Hotel and Tourism Management, Universiti Teknologi MARA, Malaysia \\ E-mail: aliffaizi@salam.uitm.edu.my \\ Zulhan Othman
}

Faculty of Hotel and Tourism Management, Universiti Teknologi MARA, Malaysia

E-mail: zulhan@salam.uitm.edu.my

Noor Azmi Ahmad

Faculty of Hotel and Tourism Management, Universiti Teknologi MARA, Malaysia

E-mail: noorazmi248@salam.uitm.edu.my

Rahayu Mokhtar

Kolej Komuniti Selayang, Malaysia

E-mail: rahayu@kkselayang.edu.my

\section{Abstract}

As market and purchasing power is frequently growing, halal foods are demanded not only within Muslim but also requested among non-Muslim. In general, the scope of halal concept is determined by how foods are prepared and served together with how they are made and processed. The assurance in foods clarifies as halal would reflect a better sense of hygiene, quality produced with the compliance of food safety. Despite the outrageous acceptance of halal industry towards processed foods, there is an issue of doubtful occurring in between. The assumptions of syubhah could be proposed as a huge issue since the sensitive uncertainty would lead to haram. Hence, this study aims to acknowledge the influence of knowledge on Doubtful Halal foods toward consumer purchasing behavior. Total of 107 consumers with different demographic participated as respondents with vary result interpretation.

Keywords: Perceived Behaviour Control, Consumer Purchased Behaviour, Halal 
INTERNATIONAL JOURNAL OF ACADEMIC RESEARCH IN BUSINESS AND SOCIAL SCIENCES

Vol. 8, No. 8, August 2018, E-ISSN: 2222-6990 @ 2018 HRMARS

\section{Introduction}

Halal concept is discussed widely in the world, especially in Muslim countries. The Halal concepts also gain attention from the non-Muslim countries, particularly in the West such as France, Belgium and Canada (Wilson, J. A,2014). This is because the rising number of Muslims community in the western countries and it is expected to increase year by year. Knowledge in Halal is important for the Muslim because it becomes as a guideline for them to seek and use the products, businesses, and services that have elements of Halal (Burhan, 2000 \& Dahalan, 2008).

The awareness of the Muslims on the Halal concept creates a competitive market and positive demand for the Halal food (Wilson, 2014 \& Bohari and Fuad, 2013). In the year 2009, Mohtar, Amirnordin and Haron (2014) reported that the market for Halal Food achieved USD3992.2 billion and it is expected growth tremendously to USD1.4 trillion in 2015. The increasing of Halal food market is related with the awareness in quality and hygienic value among muslim and non muslim customer (Wilson, 2014).

Malaysia is a Muslim country whereby Islam is the official religion. As a country that has Malay Muslim as the largest population in Malaysia, thus, the production of Halal food has become the main priority (Hassan, 2013 \& Majid, Abidin, and Chik, 2015). Thus, Jabatan Kemajuan Islam Malaysia (JAKIM) and Halal Development Corporation (HDC) have been appointed to monitor the development of Halal compliance and handling issue that related with Halal compliance in local scenery (Anynomous, 2011). Owing to that, Malaysia is a multiracial and multi-religious country, a vast food producer from different ethnic and religious beliefs appeared (David \& Dumanig, 2009). Thus, there are possibilities of doubtful halal food products in the market are high.

There are possibilities of doubtful Halal food in fresh, dry product and canned and processed food (Tieman, 2011). As the consumer that rely on packed food product in their food preparation, the presence of doubtful food products in the market creates unconditional situation among Muslim. Issues of doubtful halal food have been discussed widely among Muslim consumer (Arsat, Bachok and Chik, 2016). This situation is closely related with Muslim consumers purchase behavior towards doubtful Halal food. Previously, consumer prepares their food by themselves. However, due to the time constraint, most of the people rely on packed food product. Thus, this study is significance impact for the Halal industry towards clear understanding in Muslim consumer behaviour.

The process of consumer purchase behaviour consists identifying the set of products brands, evaluating the products, then the customer will choose among the alternatives and then making a good decision (Sumi and Kabir, 2010). In past studies on Halal Compliance discussed on the Halal purchasing (Tieman, Jack, Vorst and Ghazali, 2012), Halal awareness (Aziz and Nyen (2012) \& Alqudsi (2012), Halal brand (Borzooei and Asgari (2013) and Halal certification [17]. However, the study on consumer perception towards doubtful Halal is still limited. Thus, this study aims to examine the causal relationship between theory of planned behavior and composition of ingredients towards Muslim consumer purchased behaviour on doubtful Halal. In-depth, this study aims to access the Muslim consumer attitude, subjective norms and perceived behaviour control in purchasing Halal packed products. 
INTERNATIONAL JOURNAL OF ACADEMIC RESEARCH IN BUSINESS AND SOCIAL SCIENCES

Vol. 8, No. 8, August 2018, E-ISSN: 2222-6990 @ 2018 HRMARS

\section{Literature Review \\ Halal and Haram Food}

The basic food pattern of Muslim consumer dietary laws is based on the constraint or proscription of foods and the others. These laws are almost 1,400 years old and could be found and referred to in the Qur'an and Sunnah. Qur'an and Sunnah are the way of life, sayings, and action of Prophet Muhammad as recorded in the books of Hadith according to Islamic teaching (Bonne, Vermeir and Verbeke, 2007). It has been recorded that the Muslim, they need to differentiate between food that Halal, Haram, and Syubhah.

Halal food defined as the food that has been proven safe in terms of consumption, hygiene and wholesomeness (Mohamed, 2001 \& Rezai, Mohamed, and Shamsudin (2012). Meanwhile, Espocito, Fanizi, lannone, Palmisano, and Semeraro (2004) defined Halal food as the foods and beverage that have been acceptable for Muslim. Ahmad (2004) highlighted that Halal food is closely related with religion and dealing with cleanliness, purity, and everything from the food that we consume to the business transactions that are performed in our daily lives.

Non-Halal is the food that is forbidden and prohibited to be used or consume by Muslim (Arsat, Bachok and Chik, 2016). It also known as Haram and strictly prohibited because it may give bad impact to the consumer (Arsat, Bachok and Chik, 2016). There are foods or drinks that difficult to be identified either under the Halal or non-Halal classification and classified as 'Syubhah' or also known as questionable or doubtful halal (Alam, 2011). Meanwhile, if the status of food is suspicious either Halal or Haram, it will be considered as syubhah (doubtful halal) and the Muslim is not encouraged to consume the food.

\section{Doubtful Halal Food}

The Muslim must consume the Halal food, however, they are not encouraging to consume food that has unclear status. Schmidt and Fieldhouse (2007) defined that the food with unclear status either Halal or haram is known as syubhah, doubtful and suspected food. Meanwhile, Alam (2011) suggested that doubtful halal also can be extended to any packed food which lies within the area does not fall obviously under the Halal or non-Halal classification.

The doubtful halal is related to how the food prepares and ingredients that included in the food. The working area for food preparation must be clean to avoid cross contamination with najs derived from animal and bones with improper handling impurity (Arsat, Bachok and Chik, 2016). The food provider needs to understand that the doubtful can occurs during the food preparation and cooking process. Some of the cooking processes that related to fermentation and slaughtering need to be done in the proper way. In a fermentation process, products like soy sauce may contain $2 \%$ to $3 \%$ alcohol as a natural process of the fermentation may differ from acceptance by some other Muslim. Naturally brewed soy sauce is not Halal for consumption because it is made just like wine, containing 2-3\% ethyl alcohol in it.

There are many cases reported that packed food in the food market contains doubtful halal. Consequently, this situation provides an unfavourable condition for Muslim consumer in buying packed food. By understanding the consumer attitude, subjective norms, and perceived behaviour 
INTERNATIONAL JOURNAL OF ACADEMIC RESEARCH IN BUSINESS AND SOCIAL SCIENCES

Vol. 8, No. 8, August 2018, E-ISSN: 2222-6990 @ 2018 HRMARS

control, it may offer a better explanation to the Muslim consumer in purchasing the food product, especially in dealing with packaged food product.

\section{Theory Planned Behaviour (TPB)}

The Theory of Planned Behavior (TPB) is related with behaviors that occurred without a person's volitional control. Unlike the Theory of Reason Action (TRA), the Theory of Planned Behaviour has an additional element that is known as Perceived Behavioural Control (PBC). PBC accounts for situations where an individual has less than complete control over the behaviour. Ajzen (1991) stated that it can happen in various situations and actions. The TPB places the construct of PBC within a more general framework of relations among beliefs, attitude, intentions, and behaviour. $\mathrm{PBC}$ is held to influence both intention and behaviour.

There are three antecedents that deal with TPB which are attitude, subjective norms and perceived behavioral. Attitude is a basic psychological function and able to influence the consumer in purchase intention and consumer behavior (Fishbein and Ajzen, 1987). Attitude is the evaluation of performing a particular behaviour involving the attitude object such as buying the product (Blackwell, Miniard, and Engel, 2006). Meanwhile, Jayawardhena (2004) defined attitude as the consumer total evaluation of the product.

The relationship between attitudes towards behaviour and purchase behaviour has been discussed by numerous researchers (Jayawardhena (2004), Nguyen and Gizaw (2014) \& Dagher, Kassar and Itani (2015). In the perspective of e-shopping, Jayawardhena (2004) identified that attitude towards behaviour positively related with the e-shopping consumer behaviour. Meanwhile, in the context of green product, Dagher, Kassar, and Itani (2015) contended that attitude is positively related. Furthermore, Nguyen and Gizaw (2014) stated that attitude positively related towards purchased behaviour. Based on the above discussion, the hypotheses presented:

$H_{1}$ : There is a relationship between attitude towards behaviour and Muslim consumer purchase behaviour on doubtful halal packed food.

Subjective norms can be defined as the person's perception that most people who are important to him/her think that he/she should or should not perform the behaviour in question Ajzen (1987). According to Kholoud (2009), a subjective norm is dealing with the influence of social environment on behaviour.

From the perspective of the personal care purchases, Pandey and Soodan (2015) identified that subjective norm has the positive relation towards consumer purchased behaviour. In the perspective of food industry, subjective norm positive effect towards consumer attitude in purchasing organics food products (Irianto,2015). Considering the result of research and above discussion, the second hypotheses formulated as follows:

H2: There is a relationship between subjective norms and Muslim consumer purchased behaviour on doubtful halal packed food.

Perceived Behaviour Control (PBC) represents the individual's perceptions on the ease or difficulty of performing the behavior of interest. Ajzen (1991) stated that PBC directly influences both intention and behaviour for behaviours that are under volitional control. PBC indicates the ability of 
INTERNATIONAL JOURNAL OF ACADEMIC RESEARCH IN BUSINESS AND SOCIAL SCIENCES Vol. 8, No. 8, August 2018, E-ISSN: 2222-6990 @ 2018 HRMARS

a person to undertake the behaviour under consideration and assumption that the individual behaviour in a rational manner considering the consequence of his or her actions (Ramayah, Lee \& Lim,2012). Moreover, intentions and perceived behavioural control are positively related to behaviours.

Numerous researcher engraved TPB in their studies and relate with consumer attitude, intentions and actual consumer purchase behaviour (Pandey and Soodan, 2015 \& Irianto, 2015). For this study, perceived behavioural control is defined as the someone perceived control over other person purchasing actions. Thus, this study offers the following hypotheses:

H3: There is a relationship between perceived behaviour control and Muslim consumer purchased behaviour on doubtful halal packed food.

\section{Consumer Purchased Behaviour}

The consumer purchased behaviour is a part of the marketing and focus to learn the way how the individuals, groups or organizations making decisions on choosing, buying, using and disposing of goods (Yunus, Rashid, Ariffin and Rashid, 2013). Developing purchasing behaviour requires various factors such as the specific social, cultural, economic, legal, and political contexts, which may fluctuate pointedly between countries and even district areas that limit the generalization of research results from one country to another country's context. In the context of Halal food in Malaysia, Alam (2011) addressed that Muslim consumer awareness, perception, and their readiness or concerns about their consumption and potential purchasing behaviour affect their decision in purchasing halal food (Alam, 2011). Likewise, Yunus, Rashid, Ariffin and Rashid (2013), highlighted that Muslim consumer purchased behaviour towards halal food products are highly associated with personal, social and cultural factors such as taste, financial and cross cultural (Yunus, Rashid, Ariffin and Rashid, 2013). After reviewing the literature, the study on Muslim consumer purchasing behaviour in terms of packed products need to be investigated. The antedescent of customer planned behaviour (attitude, subjective norms and perceived behaviour control) can be related with Muslim consumer purchasing decision.

\section{Methodology}

This study was conducted in the quantitative approach through a cross sectional study. The data gathering was through a self-administered questionnaire survey. Non-probability sampling technique was used since the list of Halal packed food manufacturer is not available. The total numbers of respondents for this study were 107 Malays Muslim consumer. The sample for this study was consumers that bought Halal packed food in Kuala Selangor. The underlying assumption that Kuala Selangor formally categorized as rural areas in the states of Selangor and still considered as the traditional rural areas (Rezai, Mohamed, and Shamsudin, 2012). The questionnaire was developed and adapted based on the variables stipulated in the study framework. The questionnaire consists of three (3) sections that related with demographic profile, theory of planned behaviour, composition of ingredients and Muslim consumer purchase behavior. SEM was used to test the proposed hypotheses. 


\section{Result and Analysis \\ Demographic Profiles}

With the total of 107 respondents, most of the respondents were female (85\%) and the rest was male (15\%). The majority of respondents were age below 25 years old (54\%), followed by $25 \%$ were between 26 to 35 years old, 13\% were between 36 to 45 years old 7\% were older than 46 years old. For marital status, $57 \%$ of respondents were single, $40 \%$ were married and $3 \%$ were other. For education level, the biggest group of respondents had a bachelor degree (34\%), followed by diploma (33\%), SPM level (27\%) and master degree (6\%). Almost half of the respondents working in private sector (43\%), followed by public sector (34\%), self-employed (21\%) and unemployed accounted for $2 \%$. Majority of respondents received income between RM3100 to RM4500 (36\%), while the minority respondents received income above RM6000 (6\%), 21\% received between RM1500 to RM3000, 20\% received income between RM900 to RM1500 and lastly, $17 \%$ of respondents received income between RM4500 to RM6000.

\section{Hypothesis Testing}

As a result of presentation in the literature review, the verification of hypotheses is presented as follow:

Hypotheses 1: Attitude towards behaviour has a positive relationship to Muslim purchased behaviour on doubtful Halal packed food.

The first hypothesis is regarding attitude towards behaviour and Muslim purchased behaviour on doubtful Halal packed food. Beta value accounted $\beta=0.196$ ( $t$-value $=1.677$ ). It revealed that there is a positive relationship between attitude towards behaviour and Muslim purchased behaviour on Halal packed food and $\mathrm{H} 1$ is supported.

Hypotheses 2: Subjective norm has a positive relationship to Muslim purchased behaviour on doubtful Halal packed food.

The relationship between perceived behaviour and Muslim purchased behaviour on Halal packed food appeared with a negative sign and revealed a negative relationship $(\beta=-0.043$, $t$-value $=0.441)$. Thus, the second hypothesis is not supported.

Hypotheses 3: Perceived behaviour control has a positive relationship to Muslim purchased behaviour on doubtful Halal packed food.

This study includes the hypothesis that perceived behaviour control has a positive relationship to Muslim purchased behaviour on doubtful Halal packed food. The result highlighted that there is a positive relationship between perceived behaviour control towards Muslim purchased behaviour on doubtful Halal packed food $(\beta=0.357$, $t$-value $=3.042$ ). Thus, we can conclude that H3 is supported. 
INTERNATIONAL JOURNAL OF ACADEMIC RESEARCH IN BUSINESS AND SOCIAL SCIENCES Vol. 8, No. 8, August 2018, E-ISSN: 2222-6990 @ 2018 HRMARS

\begin{tabular}{llccc}
\hline Hypothesis & Beta & T value & Decision \\
\hline $\mathrm{H} 1 \quad \begin{array}{l}\text { Attitude -> Muslim purchased } \\
\text { behaviour }\end{array}$ & 0.196 & 1.724 & Supported \\
$\mathrm{H} 2 \quad \begin{array}{l}\text { Subjective Norm }->\text { Muslim } \\
\text { purchased behaviour }\end{array}$ & -0.043 & 0.432 & Not supported \\
$\mathrm{H} 3 \quad \begin{array}{l}\text { Perceived behaviour }->\text { Muslim } \\
\text { purchased behaviour }\end{array}$ & 0.357 & 2.968 & Supported \\
\hline Note: $* * p<0.01$ & & &
\end{tabular}

\section{Conclusion}

In a nutshell, all hypotheses have been examined. First, the results of the analysis suggest that significant relationship between attitudes towards Muslim consumer purchased behaviour on doubtful Halal packed food. This study in line with previous studies by Jayawardhena (2004) and Dagher, Kassar, and Itani (2015). Jayawardhena (2004) contended that attitude towards behaviour positively related towards the e-shopping consumer behaviour. A recent study by Dagher, Kassar, and Itani (2015) addressed that attitude has a positive relationship with purchasing behavior in purchasing green products. Likewise, it can be concluded that attitude positively related with Muslim consumer purchase behavior in purchasing Halal packed products.

The second hypotheses showed that there is a positive relationship between subjective norm and Muslim purchased behavior control. However, the finding discovered that hypothesis has been rejected because due to the negative value in the relationship between subjective norm and Muslim consumer purchased behaviour on Halal packed food. This result against previous research by Kavaliauske and Ubartaite (2014). Kavaliauske and Ubartaite (2014) indicated that subjective norm and consumer's purchased behaviour are engaged, significant and positive. Meanwhile, Irianto (2015) claimed that there is a positive effect between subjective norm and consumer attitude in purchasing the organic food products, however, in this study vice versa. Thus, it seems that people surrounded Muslim consumer does not give a big impact towards Muslim consumer in buying Halal packed food.

The third hypotheses show that a positive relationship between perceived behaviour control and Muslim purchased behaviour control. This results in line with previous research by Pandey and Soodan (2015) \& Irianto (2015) identified significant findings indicated that attitudes and perceived behavioural control have positive and strong relationship with purchased behaviour. It can be assumed that a higher level of education helps the consumer to control their purchasing decision towards doubtful Halal packed products in the market.

Lastly, the finding also suggests that the composition of ingredients derived positive impact towards Muslim consumer purchased behaviour on halal packed food. It has been discussed in the perspective of organic food products, whereby the composition of ingredients become a vital role that influences consumer purchasing behavior. The packed food should clearly display the list of ingredients and Halal identification to avoid doubt for Muslim consumer. 
INTERNATIONAL JOURNAL OF ACADEMIC RESEARCH IN BUSINESS AND SOCIAL SCIENCES

Vol. 8, No. 8, August 2018, E-ISSN: 2222-6990 @ 2018 HRMARS

In conclusion, attitudes, subjective norms, and purchase behavior control giving positive significant towards Muslim consumer in making decision in buying Halal packed food. In addition, the ingredients of Halal food also should be considered.

\section{Acknowledgment}

The work described in this study was supported by the Research Interest Group (RiG) Tier 5 - Food Service Quality, Centre of Research Excellence (CoRe), Management Science (MS), Universiti Teknologi MARA, Malaysia (UiTM)

\section{Corresponding Author}

\section{Nur Ida Fatihah Bt Che Shalifillizam}

Faculty of Hospitality and Tourism, Taylor's University 1, Jalan Taylor, 47500 Subang Jaya, Selangor, Malaysia

E-mail: nuridafatihahcheshalifullizam@sd.taylors.edu.my

\section{References}

Ahmad, R. W. (2004). Halal perspective. The Halal Journal, 3

Ajzen, I. (1987). Attitudes, traits, and actions: Dispositional prediction of behavior in personality and social psychology doi:10.1016/S0065-2601(08)60411-6

Ajzen, I. (1991). The theory of planned behavior. Organizational Behavior and Human Decision Processes, 50(2), 179-211. doi:10.1016/0749-5978(91)90020-T

Alam, S.S. \& Sayuti, N.M (2011). Applying the Theory of Planned Behavior (TPB) in Halal food purchasing. International Journal of Commerce and Management, 21(1), 8-20

Alqudsi, S.G (2013) Awareness and Demand for 100\% Halal Supply Chain Meat Products, ProcediaSocial Sciences Behavioural Sciences 130, 167-178

Anonymous (2011). Halal Development Corporation

Arsat, A., Bachok, S., Chik, C. T., \& Baba, N. (2016). Preferences towards quality, trust, and trend in halal restaurant. Paper presented at the Proceedings of the 3rd International Hospitality and Tourism Conference, IHTC 2016 and 2nd International Seminar on Tourism, ISOT 2016, 735-738. Retrieved from www.scopus.com

Aziz, Y.A., \& Nyen, V.C (2012) The role of Halal awareness, Halal certification, and marketing in determining Halal purchased intention among non-Muslin in Malaysia: A structural Equation Modelling Approach. Journal of International Food and Agribusiness Marketing 25:1,1-23

Burhan, A. (2000). Consumer behavior and religiosity of Muslim community in Klang Valley: Consumer perception on halal and non halal in products and services. University Malaya

Blackwell, R., Miniard, P. and Engel, J. (2006) "Consumer behavior", Mason: Thompson

Bohari, A.M, Hin, C.W \& Fuad, N. (2013). The competitiveness of halal food industry in Malaysia: A SWOT-ICT analysis. Geografia Online Malaysia Journal of Society and Space 9 Issue 1 (1 - 9) 1. ISSN 2180-2491

Bonne. K., Vermeir. I., F., B.-B., \& Verbeke, W. (2007). Determinants of halal meat consumption in france. British food 367- 386.

Borzooei, M \& Asgari, M. (2013) Establishing a global Halal-hub: In depth interviews. International Journal of Academic Research in Business and Social Sciences, Vol, No. 10 ISSN 2222-6990 
INTERNATIONAL JOURNAL OF ACADEMIC RESEARCH IN BUSINESS AND SOCIAL SCIENCES

Vol. 8, No. 8, August 2018, E-ISSN: 2222-6990 @ 2018 HRMARS

Dagher, G.K., Kassar, A.N., \& Itani, O. (2015). The Impact of Environment Concern and Attitude on Green Purchasing Behavior: Gender as The Moderator. Contemporary Management Research, 11(2), 179-206. http://dx.doi.org/10.7903/cmr.13625

Dahalan, Z. (2008). Kecenderungan umat islam terhadap konsep pemakanan halal: Kajian di Uitm Pulau Pinang. Paper presented at The ECER Regional Conference Malaysia

David.M.K \& Dumanig.F.P, (2009). National unity in Multi Ethnics Malaysia: A critical discourse analysis of Tun Dr. Mahathir's Political speeches.

Esposito, F., Fanizzi, N., lannone, L., Palmisano, I., \& Semeraro, G (2004).: Induction and revision of terminologies. In: de Mataras, R.L., Saitta, L. (eds.) Proceedings of the 16th European Conference on Artificial Intelligence, pp. 1007-1008. IOS Press, Amsterdam

Fishbein, M., \& Ajzen, I. (2011). Predicting and changing behavior: The reasoned action approach. Predicting and changing behavior: The reasoned action approach (pp. 1-518) DOI:10.4324/9780203838020

Gotschi, E., Vogel, S., \& Lindenthal, T. (2007). High school students attitudes and behaviour towards organic products: Survey results from Vienna. Institute for Sustainable Economic Development, DoE

Hassan, H. F(2013). Professorial Lecture: Halal Food Marketing: Dare to Win!. ISBN 978-967-363-4989

Irianto, H. (2015). Consumers attitude and intention towards organics food purchase: An extension of theory of planned behaviour in gender perspective. International Journal of Management, Economics and Social Sciences (IJMESS), Vol. 4, Iss. 1, pp. 17-3. ISSN 2304-1366,

Jayawardhena, C. (2004). Personal values' influence on e-shopping attitude and behaviour. Internet Research, 14(2), 127-138. doi:10.1108/10662240410530844

Kavaliauske, M., \& S. Ubartaite, (2014). Ethical Behaviour: Factors Influencing Intention to Buy Organic Products in

Kholoud, I. A. Q. (2009). Analyzing the use of UTAUT Model in Explaining an Online Behaviour: Internet Banking Adoption, Ph.D. Dissertation, Department of Marketing and Branding, Brunei University.

Kotler, P. \& Keller K, (2012). Marketing management. Twelfth edition. New Jersey: Pearson Prentice Hall

Majid.M.A.A, Abidin. I.H.Z., \& Chik.C.T (2015). Issues of Halal Food Implementation in Malaysia. Journal of Apllied Environmental and Biological Sciences, 5(6S) 55-56

Mohtar, N.M., Amirnordin, N.A., \& Haron, H.D. (2014). Ayamas Food Corporation Sdn. Bhd. A study on the factors of consumer behaviour towards Halal Product selection.

Mohamed, S. (2001). Marketing niche for halal food supply: Framework for the establishment of an international halal food market. Food Security from the Islamic Perspective, $1-21$

Nguyen, T. H., \& Gizaw, A. (2014). Factors that influence consumer purchasing decision of Private Label Food Product: A case study of ICA Basic (Dissertation). Retrieved from http://urn.kb.se/resolve?urn=urn:nbn:se:mdh:diva-24654

Noordin, K., Muwazir, M. R., \& Madun, A. (2014). The Commercialization of Modern Islamic Insurance Providers: A Study of Takaful Business Frameworks in Malaysia. International Journal of Nusantara Islam, 2(1), 1-13

Pandey, A.C. \& Soodan, V. (2015). Roles of consumer attitudes, beliefs and subjective norms as predictor as purchase behaviour: A study of personal care purchase. International Conference on 
INTERNATIONAL JOURNAL OF ACADEMIC RESEARCH IN BUSINESS AND SOCIAL SCIENCES

Vol. 8, No. 8, August 2018, E-ISSN: 2222-6990 @ 2018 HRMARS

Issues in Emerging Economies (ICIEE), 29-30th January 2015. The Business \& Management Review, Volume 5, Number 4, pp 284-291

Ramayah, T., Lee, J. W. C., \& Lim, S. (2012). Sustaining the environment through recycling: An empirical study. Journal of Environmental Management, 102, pp 141-147. doi:10.1016/j.jenvman.2012.02.025

Rezai, G. Mohamed Z., \& Shamsudin, M.N.(2012). Non muslims consumers' understanding of halal principles in Malaysia. Journal of Islamic Marketing, Vol.3 Issue 1 pp. 35-46.

Schmidt, A., \& Fieldhouse, J.(2007) The World Religions Cookbook Connecticut: Greenwood Press

Sumi, R. S. \& Kabir, G. (2010). Analytical hierarchy process for higher effectiveness of buyer decision process. Global Journal of Management and Business Research, 10(2), 2-9.

Tieman, M. (2011). The application of Halal in supply chain management: In-depth interviews. Journal of Islamic Marketing, 2 (2), 186-195.

Tieman. M, Jack G.A.J.Vorst.V.D., \& Ghazali.M.C, (2012), "Principles in halal supply chain management", Journal of Islamic Marketing, Vol. 3 Iss: 3, pp.217-243

Wilson, J. A. (2014). Islamic economics 2.0-creating a halal wealth and knowledge economy. Zawya, 1-7.

Yunus, N.S.N.M, Rashid.W.E., Ariffin.N.M \& Rashid.N.M (2013) Muslim's purchased intention towards non-muslim's Halal packaged food manufacturer. Procedia Social and behavior sciences 130, pp $145-154$ 